\title{
Locations of International Labor Organizations
}

\section{Anatoli M. Ilyashov}

University of the District of Columbia

It is important for the historian or scholar of the international labor movement to be aware of the contemporary structure and activities of the international labor confederations. Too often historians fail to take these organizations seriously as significant repositories of information on trade union policy. However, since the days of the First International in the nineteenth century, when efforts arose to unify many of the demands of national labor movements into one general political movement of all workers, trade union confederations built across national lines have functioned to fulfill this original need and political aim of workers everywhere. The names and addresses of international labor organizations listed below will hopefully provide the historian or student of labor with some overall picture of the institutional framework of trade unions on a global scale. Its usefulness becomes more apparent in the modern period, where one is engaged in the analysis of various labor movements in the post World War II period.

\section{INTERNATIONAL LABOR ORGANIZATIONS}

International Labor Organization (ILO)

4 route des Morillons

CH-1211 Geneva 22, Switzerland

Washington Branch ILO

1750 New York Ave., N.W. Rm. 330

Washington, D.C. 20006

International Confederation of Free Trade Unions (ICFTU)

Rue Montagne-aux-Herbes-Potageres 37-41

B-1000 Brussels, Belgium

World Federation of Trade Unions (WFTU)

Namesti Curieovych 1

11688 Prague 1, Czechoslovakia

World Confederation of Labor (WCL) (formerly

the Christian CISC)

50, rue Joseph II

B-1040 Brussels, Belgium f. June 1919, League of Nations; 1946, United Nations

m. 135 Member States as of April 25, 1977

f. Dec. 1949, London

m. 56.2 million in 88 countries ( 1977 est.)

f. Oct. 1945, Paris

m. 160 million in 70 countries ( 1977 est.)

f. 1920, The Hague

m. 14.5 million in 80 countries ( 1973 est.) 
INTERNATIONAL TRADE SECRETARIATS, INTERNATIONALS, \& FEDERATIONS

INTERNATIONAL TRADE SECRETARIATS (affiliated with the ICFTU)

International Federation of Building and Woodworkers (IFBWW)

27-29 rue de la Coulovreniere 1204 Geneva, Switzerland

International Federation of Chemical, Energy, and General Workers' Unions (ICEF)

58 rue de Moillebeau

1211 Geneva, Switzerland

International Federation of Commercial, Clerical and Technical Employees (FIET)

15 avenue de Balexert

1210 Chatelaine-Geneva, Switzerland

Universal Alliance of Diamond Workers (UADW) Plantin en Moretulei 66-68

Antwerp, Belgium

International Secretariat of Entertainment Trade Unions (ISETU)

Maria Theresienstr. 11

1090 Vienna, Austria

International Union of Food and Allied Workers'

Associations (IUF)

Rampe du Pont Rouge

1213 Petit Lancy, Switzerland

International Graphical Federation (IGF)

Monbijoustr. 73

3007 Berne, Switzerland

International Federation of Journalists (IFJ)

International Press Center,

Blvd. Charlemagne 1

1041 Brussels, Belgium

International Metalworkers' Federation (IMF)

54 bis route des Acacias

1227 Geneva, Switzerland

Miners' International Federation (MIF)

75-76 Blackfriars Road

London, S.E.1, England

International Federation of Plantation, Agricultural and Allied Workers (IFPAAW)

17 rue Necker

1201 Geneva, Switzerland

Postal, Telegraph, and Telephone International (PTTI)

36 avenue de Lignon

1219 Geneva, Switzerland f. 1934 (thru mergers)

m. 3 million in 55 countries*

f. 1907

m. 5.5 million in 66 countries

f. 1904

m. 6.4 million in 80 countries

f. 1905

m. 11,000 in 4 countries

f. 1965

m. 350,000 in 35 countries

f. 1920 (thru mergers)

m. 1.8 million in 60 countries

f. 1949 (thru mergers)

m. 650,000 in 26 countries

f. 1952

m. 83,000 in 25 countries

f. $1893 / 1904$

m. 13.7 million in 70 countries

f. 1890

m. 1.2 million in 32 countries

f. 1960 (thru mergers)

m. 1.6 million in 50 countries

f. 1911

m. 3.3 million in 86 countries

* 1978-1979 estimates 
INTERNATIONAL TRADE SECRETARIATS (continued)

Public Services International (PSI)

Holstrom House, Central Way

Feltham, Middlesex, England

International Federation of Free Teachers' Unions (IFFTU)

11 avenue Georges Bergmann

1050 Brussels, Belgium

International Textile, Garment and Leather

Workers' Federation (ITGLWF)

8 rue Joseph Stevens

1000 Brussels, Belgium

International Transport Workers Federation (ITF)

133-135 Great Suffolk Street

London, S.E.1, England f. 1935 (thru mergers)

m. 6 million in 67 countries

f. 1928

m. 3 million in 52 countries

f. 1970 (thru mergers)

m. 5.4 million in 63 countries

f. 1896

m. 4.4 million in 90 countries

TRADE UNIONS INTERNATIONAL (affiliated with the WFTU)

Trade Unions International of Agricultural, Forestry, and Plantation Workers (TUIAFPW)

Opletalova 57

Prague 11000, Czechoslovakia

Trade Unions International of Workers of the Building, Wood and Building Materials Industries (TUIBWM)

Fredrikinkatu F28B13, Box 10281

00101 Helsinki, Finland

Trade Unions International of Chemical, Oil and Allied Workers (ICPS)

Benczur u. 45

H-1415 Budapest, Hungary

Trade Unions International of Workers in Commerce (TUIWC)

Opletalova 57

Prague 11000, Czechoslovakia

Trade Unions International of Workers of the Food, Tobacco and Beverages Industries \& Hotel, Cafe and Restaurant Workers

4 , rue de 6 Septembre

Sofia, Bulgaria

Permanent Committee of Graphic Arts Unions \% TUI Opletalova 57

Prague 11000, Czechoslovakia

International Organization of Journalists (IOJ)

Parizska 9

Prague 11001, Czechoslovakia

Trade Unions International of Workers in the Metal Industry (TUIWMI)

B.P. 158

Moscow K9, USSR f. Dec. 1949, Warsaw

m. 41 million in 46 countries

f. July 1949 , Milan

m. 15 million in 45 countries

f. March 1950, Budapest

m. 6.9 million in 33 countries

f. June 1959, Prague

m. 15 million in 45 countries

f. Nov. 1949, Sofia

m. 14 million in 49 countries

f. unavailable

m. unavailable

f. 1926, Paris; 1946, Copenhagen

m. unavailable

f. June 1949, Turin

m. 20 million in 26 countries

(1977) 
TRADE UNIONS INTERNATIONAL (continued)

Miners' Trade Unions International (MTUI)

U1. Kopernika 36/40

Warsaw 00 924, Poland

Trade Unions International of Public and Allied

Employees (TUIPAE)

Franzosische Str. 47, Postfach 1322

DDR-108 Berlin, Germany GDR

World Federation of Teachers' Unions (FISE)

Wilhelm Wolff-Str. 21

DDR-111 Berlin, Germany GDR

Trade Unions International of the Textile, Clothing, Leather and Fur Workers (TUITCLF)

Opletalova 57

Prague 11001, Czechoslovakia

Trade Unions International of Transport, Port and

Fishery Workers

Opletalova 57

Prague 11001, Czechoslovakia f. 1949, Warsaw

m. ca. 6 million in 22 countries

(1976)

f. Oct. 1949, Berlin

m. 24 million in 41 countries

f. 1946, Paris

m. 16 million in 50 countries

f. July 1958 , Sofia (mergers)

m. ca. 10 million in 29 countries

(1976)

f. March 1953, Prague

(mergers)

m. 16.5 million in 50 countries

(1977)

\section{FEDERATIONS (of the WCL)}

World Federation of Agricultural Workers

50, rue Joseph II

B-1040 Brussels, Belgium

World Federation of Building and Woodworkers'

Unions

Kromme Nieuwe Gracht 22, PB 414

Utrecht, Netherlands

World Federation for Energy, Chemical and Miscellaneous Industries

26/32 Avenue d'Auderghem

1040 Brussels, Belgium

World Federation of Workers in the Food, Drink, Tobacco and Hotel Trades

50 , rue Joseph II

f. 1921

m. 3.4 million in 25 countries

(1975)

f. 1937

m. $330,000(1977)$

B-1040 Brussels, Belgium

International Federation of Christian Trade Unions in the Graphic and Paper Industries

f. 1920

m. $150,000(1976)$

P.C. Hooftstraat, 170-172, P.O. Box 5522

Amsterdam, Netherlands

World Federation for the Metallurgic Industry

50 , rue Joseph II

B-1040 Brussels, Belgium

f. 1920

m. 250,000 in 25 countries

f. $1925 / 1946$

m. $36,000(1975)$

f. 1920

m. $500,000(1976)$

International Federation of Christian Miners'

Unions

f. 1901

m. 220,000 in 10 countries

26/32 Avenue d'Auderghem

1040 Brussels, Belgium 
FEDERATIONS (of the WCL) (continued)

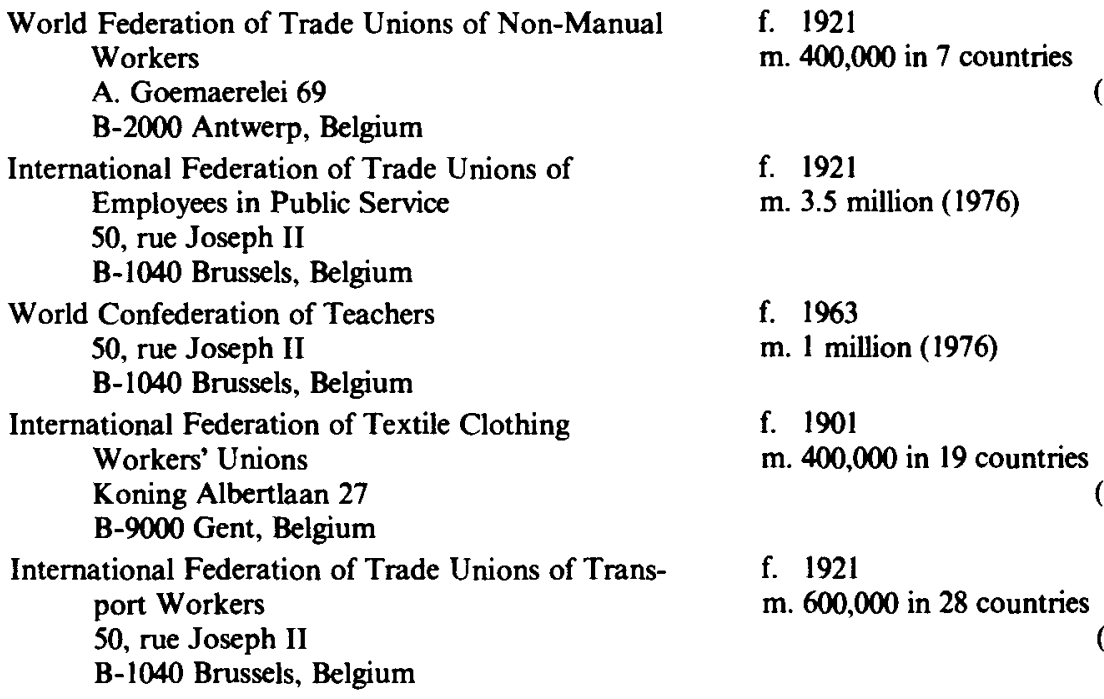

\section{REGIONAL LABOR ORGANIZATIONS}

Africa:

Organization of African Trade Union Unity

(OATUU)

P.O. Box M. 386

f. April 1973, Addis Ababa, Ethiopia

Accra, Ghana

m. unavailable; 52 countries

Asia:

Asian Regional Organization of the ICFTU

P-20 Green Park Extension

New Delhi - 110016, India

Caribbean:

Trade Union Council of Caribbean Workers (TUCCW)

Emmastraat 27, Esquina Yzerstraat 59

Curacao, Netherlands, Antilles

Europe:

European Trade Union Confederation (ETUC)

Rue Montagne-aux-Herbes-Potageres 37

B-1000 Brussels, Belgium

f. May 1951, Karachi, Pakistan

m. 22.8 million in 18 countries

(1976)

f. 1970, Willemstad (Curacao)

m. unavailable; ca. 15 states and territories

(affiliated to CLAT)

(1976)

Contains six industry committees (1975):

European Metalworkers' Federation in the Community (EMF)

38 rue Rosse-aux-Loups

1000 Brussels, Belgium

f. Feb. 1973, Brussels

m. 37 million in 17 countries

(1976) 
REGIONAL LABOR ORGANIZATIONS (continued)

European Federation of Agricultural Workers' Unions in the Community (EFA)

37 rue Montagne-aux-Herbes-Potageres 1000 Brussels, Belgium

Trade Union Committee of the Post, Telephone and Tele-Communication Service for the EEC Countries

36 avenue de Lignon

1211 Le Lignon

Geneva, Switzerland

European Regional Organization of the International Federation of Commercial, Clerical and Technical Employees (EURO-FIET)

10 rue de Tournai 1000 Brussels, Belgium

Metalworkers and Miners Inter-Trade Union Committee (ICFTU-ECSC)

58 avenue de la Liberte

Case Postale 20006

Luxembourg

European Committee of the International Secretariat of Entertainment Trade Unions

Klotsnmoor 31

2000 Hamburg, Germany FRG

Other affiliated industry committees:

Trade Union Committee for Transport in the Community

37 rue Montagne-aux-Herbes-Potageres

1000 Brussels, Belgium

European Trade Union Committee for Textiles, Clothing and Leather

16 Oaselaan

191900 Overijse, Belgium

EEC Coordination Committee of the International Federation of Chemical Workers and other Industries

Koningsworther Platz 6

3 Hannover, Germany FRG

Joint Committee of the Building and Woodworkers in the EEC

Rue Haute, 26-28

1000 Brussels, Belgium

European Trade Union Committee of Food and Allied Workers in the Community

Gertrudenstrasse 9

Hamburg, Germany FRG 
REGIONAL LABOR ORGANIZATIONS (continued)

Latin America:

Central Latinoamericana de Trabajadores (CLAT) Apartado 6681

Caracas 101, Venezuela

Congreso Permanente de Unidad Sindical de Los

Trabajadores de America Latina

(CPUSTAL)

Apartado 3003

Panama 3, Panama

Organizacion Regional Interamericana de Trabajadores (ORIT-ICFTU)

Huatabampo 6

Mexico 7 D.F., Mexico

Middle East:

International Confederation of Arab Trade Unions

(ICATU)

Ramses Building, Ramses Square

P.O. Box 1041

f. Dec. 1954, Santiago, Chile

m. 6.5 million

(1976)

f. Sept. 1962, Santiago, Chile

m. unavailable; ca. 17 countries

f. Jan. 1951, Mexico City

m. 28 million

(1976)

Cairo, Egypt

(to be moved to Syria)

Contains ten Arab Trade Union Secretariats (1976):

Arab Federation of Oil, Metal and Chemical Workers (f. 1961)

Arab Transport Federation (f. 1966)

Arab Federation of Agricultural Workers (f. 1969)

Arab Federation of Weavers (f. 1969)

Arab Federation of Food Industry Workers (f. 1969)

Arab Federation of Postal, Telephone and Telegraph Workers (f. 1969)

Arab Federation of Building, Wood and Building Materials Workers (f. 1972)

Arab Federation of Workers in Commerce (f. 1972)

Arab Federation of Bank, Insurance and Finance Workers (f. 1972)

Arab Federation of Metal, Engineering and Electronic Industry Workers (f. 1975)

f. March 1956, Damascus, Syria

m. 10 million in 13 countries 


\section{SOURCES}

For further information, contact: Prof. Anatoli M. Ilyashov

Labor Studies Center

International Labor Concentration

University of the District of Columbia

724 Ninth St., N.W. Room 528

Washington, D.C. 20001

Coldrick, A.P. and Jones, Philip, The International Directory of the Trade Union Movement, Facts on File, New York, 1979.

Encyclopedia of Associations, 16th Edition, Gale Research Co., Detroit, 1981.

Windmuller, John P., The Shape of Transnational Unionism: International Trade Secretariats, U.S.

Department of Labor, Bureau of International Labor Affairs, December 1979.

World Guide to Trade Associations, R.R. Bowker Co., New York \& London, 2 volumes, 1973.

Yearbook of International Organizations, 17th Edition, Union of International Associations, Brussels,

Belgium, 1978. 